\title{
Correction to: Understanding mentoring relationships in China: Towards a Confucian model
}

\author{
Abby Jingzi Zhou ${ }^{1}$ Émilie Lapointe ${ }^{1} \cdot$ Steven Shijin Zhou ${ }^{1}$ \\ Published online: 7 March 2019 \\ (C) Springer Science+Business Media, LLC, part of Springer Nature 2019
}

\section{Correction to: Asia Pac J Manag https://doi.org/10.1007/s10490-018-9589-5}

The author missed to acknowledge National Science Foundation of China for the financial support. Kindly see below Acknowledgement section:

Acknowledgements This study was financially supported by the National Science Foundation of China (NSFC-71732007).

Publisher's note Springer Nature remains neutral with regard to jurisdictional claims in published maps and institutional affiliations.

The online version of the original article can be found at https://doi.org/10.1007/s10490-018-9589-5

Steven Shijin Zhou

steven.zhou@nottingham.edu.cn

1 Nottingham University Business School China, 199 Taikang East Road, Ningbo 315100, China 